\title{
$\underline{\text { Variability of human pluripotent stem cell lines }}$
}

\begin{abstract}
:
Human pluripotent stem cells derived from embryos (human Embryonic Stem Cells or hESCs) or generated by direct reprogramming of somatic cells (human Induced Pluripotent Stem Cells or hiPSCs) can proliferate almost indefinitely in vitro while maintaining the capacity to differentiate into a broad diversity of cell types. These two properties (self-renewal and pluripotency) confers human pluripotent stem cells a unique interest for clinical applications since they could allow the production of infinite quantities of cells for disease modelling, drug screening and cell based therapy. However, recent studies have clearly established that human pluripotent stem cells lines can display variable capacity to differentiate into specific lineages. Consequently, the development of universal protocols of differentiation which could work efficiently with any human pluripotent cell line is complicated substantially. As a consequence, each protocol needs to be adapted to every cell line thereby limiting large scale applications and precluding personalised therapies. Here, we summarise our knowledge concerning the origin of this variability and describe potential solutions currently available to bypass this major challenge.
\end{abstract}

\section{Introduction}

The derivation of human embryonic stem cells (hESCs) [1] opened exciting opportunities for translational research and regenerative medicine. Almost a decade later, direct reprogramming of human somatic cells to pluripotency [2] promised to overcome ethical limitations associated with human embryos and enable personalised therapies. However, the clinical applications of hESCs and hiPSCs continue to be limited by their inherent variability in differentiation capacity [3-5]. Indeed, protocols of differentiation appear to work efficiently only with specific cell lines thereby precluding the use of a broad spectrum of human pluripotent stem cells (hPSCs). This challenge is exacerbated by the lack of a precise test to evaluate the level of reprogramming in hiPSCs. In contrast to mouse ESCs, hPSCs pluripotency cannot be assessed through chimera formation or tetraploid complementation assays. As a consequence, reprogramming of human cells can only be confirmed through relatively crude characterisations such as gene expression profiling, in vitro differentiations or teratoma formation none of which is sufficient to determine the capacity of differentiation of individual hiPSCs into a specific cell types. Thus, the origins of this functional variability remain an active field of investigation within the stem cell community. Some of the previous findings and more recent developments will be discussed here.

\section{Gene expression and signalling variability}

There has been a diversity of attempts to find markers characterising hPSC variability and predicting their capacity of differentiation. Indeed, differences in gene expression controlling endogenous signalling are likely to alter cellular behaviour and differentiation potential in vitro. This variability in signalling pathway activity may be counteracted by line specific optimisation of differentiation protocols, adapting the concentration of cytokines and inhibitors according to the cell line used [6]. Accordingly, several reports have shown that varying gene expression profiles in hPSCs could be associated with divergent capacities of differentiation. Blauwkamp and colleagues correlated the expression of early lineage markers 
in undifferentiated hPSCs [7] with the level of endogenous Wht signalling resulting in distinct differentiation propensities. Elevated Wnt would thereby lead to enhanced differentiation potential towards mesendoderm, which was confirmed by a separate report [8]. However, wnthigh and wnt-low subpopulations in normal culture seem to change dynamically rather than represent a stable state.

The expression of micro-RNAs was shown to serve as an indicator of neural differentiation propensity [9]. In a recent study, Nishizawa and colleagues compared 35 different hiPSC lines of different origin and four hESC lines in their ability to form hematopoietic cells [10]. This analysis revealed that the differentiation potential of hPSC lines could correlate with the expression of IGF2. This gene is not directly implicated in the hematopoietic differentiation, but seems to serve as an indicator of chromatin accessibility at loci of mesendodermal genes which could render them more amenable for activation. Interestingly, the maturation capacity of different lines was less correlated with varying gene expression patterns, but instead seemed to be influenced by changes in DNA methylation [10] suggesting that epigenetic rather than genetic regulations could be involved. Importantly, this study seems to contradict a previous report showing that the endogenous level of Nodal growth factor in hESCs could predict their capacity to differentiate into blood progenitors [11]. This underlines the difficulty of such experimental comparisons requiring a larger number of independent experimental samples that can be easily influenced by culture conditions, handling skills, methods of analysis and the quality of the hPSC lines used.

\section{DNA methylation and epigenetic memory}

Variations in the transcriptome could originate from a diversity of mechanisms. One source could be epigenetic differences induced by either abnormal/incomplete reprogramming [12] or by culture conditions [13-16]. In particular, hiPSCs have been under intense scrutiny as to their similarity with hESCs. Indeed, a methylation analysis of preselected CpG sites concluded that there is a core set of aberrantly methylated genes that can distinguish hiPSCs from hESCs regardless of the donor cell type [17]. This "reprogramming-associated epigenetic signature" was characterised mainly by hypermethylation at specific loci. This is in accordance with an unbiased whole-genome methylome analysis that identified regions of aberrant methylation which also persists in differentiated cell types derived from iPSCs [18]. It was suggested that these epigenetic variations could either be a function of the reprogramming process itself [19] or they could depend on the reprogramming method used to generate these lines [20]. Aberrant $\mathrm{CpG}$ methylation demonstrated to be heavily influenced by clone-specific effects and seems to be correlated with MYC binding motifs [21], therefore it may be desirable to omit C-MYC in the reprogramming cocktail, which has been shown in mice to reduce tumorigenicity [22,23]. Furthermore, non-CG methylation can also serve as marker for predicting the potential of hPSCs to differentiate into definitive endoderm, thus linking variability in DNA methylation with differentiation phenotypes [24].

Several studies have instead attributed differences between hiPSCs lines to persistent remnants of epigenetic or transcriptional profiles of the donor cell type [25-28]. This retention of some of the characteristics of the somatic cell type of origin was termed epigenetic memory and was speculated to be at least in part responsible for the variability in differentiation capacity of different hiPSC lines [29-31]. However, the impact of epigenetic memory seems to vary between laboratories, somatic cell types and methods of reprogramming. Indeed, several reports could not detect any major influences of donor cell type on the capacity of differentiation while showing that hiPSCs from different donors are more divergent than hiPSCs originating from different somatic cell types of the same donor [32-34]. Finally, 
epigenetic memory appears to decrease after prolonged cell culture in vitro. Further reaffirming this notion, conclusive studies of genetically matched lines found hESC and hiPSC to be equivalent and imputed the few recorded differences to transcriptional noise $[35,36]$. Considered together, these results suggest that epigenetic variation and especially DNA methylation could have a key role in defining the differentiation capacity of hiPSCs. However, the source of this epigenetic variability and its functional impact on differentiation capacity remains controversial.

\section{Genetic factors}

Genetic variability could also have a significant influence on the capacity of hPSCs to self-renew and to differentiate. hiPSC lines with different genetic backgrounds could express divergent levels of receptors, transcription factors and growth factors which in turn could affect their capacity to respond to specific culture conditions. Recently even mutations in mitochondrial DNA have been raised as a potential additional source of variability [37]. However, the link between variability and genetic background has proven challenging to demonstrate with hESCs. Indeed, the limited number of hESC lines available precludes large scale studies necessary for genetic analyses. In addition, the variability induced by the process of derivation is difficult to evaluate since production of several hESC lines with the same genetic background is very challenging. Thus, the importance of genetic background has started to be investigated with hiPSCs. Several studies have now revealed that the transcriptome of hPSCs generated from different donors is more divergent than the transcriptome of hPSCs generated from the same donor or even from hPSCs from different tissue types of the same donor [35,38-40]. These reports also showed the existence of pluripotent specific Quantitative Trait Loci (QTL) and that allele specific variations can result in different levels of gene expression. Taken together, these reports suggest that genetic factors could influence key characteristics of hiPSCs including their capacity to differentiate into specific cell types. Nonetheless, functional links of differentiation capacity and molecular mechanisms involved remain to be fully uncovered especially the existence of specific "Differentiation-QTL". The current development of large scale initiatives such as HIPSCl (www. hipsci.org) or the Next Gen consortium (http://www.cell.com/consortium/NextGen) could address this limitation (see table for a more comprehensive list of initiatives). One such study from the Next Gen consortium identified polycomb targets as another non-genetic potential cause of heterogeneity of hPSC lines [39]. Due to the potential to generate iPSCs from various genetic backgrounds these could serve as a good tool to validate GWAS targets in patient and control lines [41]. These projects are deriving a large number of hiPSC lines from healthy donors which could be used to perform detailed genetic analyses to link genomic regions with capacity of differentiation. Such mechanisms have recently been uncovered in drosophila where thousands of developmental specific QTL have been identified in enhancers controlling expression of regulators directing embryonic development [42]. Pashos and colleagues have studied QTLs and allele specific expression in iPSCs and hepatocyte like cells and suggested that hiPSCs are a good model to discover and study genes and functional variants leading to complex human traits [43]. The identification of human "differentiationQTL" and associated mechanisms could have a major impact on our understanding of development and disease progression. Indeed, such mechanisms are likely to control the activity of key signalling pathways and/or epigenetic networks involved in organogenesis and tissue repair.

\section{$\underline{X \text {-inactivation and imprinting }}$}


Another factor displaying variability in different hPSC lines is the inactivation of the $\mathrm{X}$ chromosome. While the usual state of female somatic cells (one $X$ chromosome active and one inactive, $\mathrm{XaXi}$ ) is largely maintained during reprogramming, XaXa cells have been reported [44]. Furthermore, the inactivation of one $X$ chromosome is frequently eroded with prolonged time in culture [45]. Indeed, a study from the Progenitor Cell Biology Consortium found that one of the major epigenetic differences between 58 different hiPSC lines were differential methylation patterns related to the X-chromosome [46]. The breakdown of $X$ inactivation has been associated with increased expression of oncogenes and reduced developmental potential both of which could affect cell fate decisions in hPSCs [45,47]. DNA methylation is also heavily influencing the allele-specific expression of imprinted genes. Several studies have reported changes in imprinting in mouse and human iPSC lines as a result of either prolonged culture or the reprogramming process [48-50] while others have found imprinting to be relatively stable [51]. Changes in the imprinted Dlk1-Dio3 cluster in mouse iPSCs have been correlated with their level of pluripotency and the ability to contribute to all cell types [52] thereby implying major differences in developmental potential. Finally, global loss of imprinting seems to heavily increase oncogenic potential [53]. Therefore, proper imprinting is essential to avoid functional impairment of PSCs and their derivatives. Most of the aspects mentioned above can be influenced by in vitro culture of hPSCs. While aberrant hypermethylation patterns and CNVs seem to decrease over time in iPSCs [54-56], erosion of $X$ inactivation is more likely to occur [45]. Importantly, genetic and epigenetic alterations have been reported in hPSCs by many studies and can heavily influence their functional properties and oncogenic potential [57]. Culture conditions can affect the epigenetic status of hPSCs and constitute a major factor of inter-laboratory variability. Potentially, automated derivation and culture of iPSCs together with standardised culture conditions could decrease this source of variability [58]. It has further been suggested that reverting hPSCs to an earlier developmental state (ground state) could erase epigenetic signatures [59], however it has not been proven experimentally whether this will decrease variability of PSCs. Besides, as mentioned above there can be grave consequences of deleting crucial epigenetic marks such as imprinting. Thus, the details of an ideal hPSC culture minimising variability remain to be determined.

\section{Conclusions}

Variability between hPSC lines represents a major challenge for clinical applications since it could impair the development of personalised medicine. However, such variability especially when linked to genetic background could be used advantageously to investigate complex genetic mechanisms involved in disease using hPSC models. Nonetheless, variation induced by abnormal epigenetic profiles needs to be better understood and controlled. Improving methods of reprograming might decrease the background noise induced by such epigenetic mechanisms independent of the genetic background. Precise delivery of reprogramming factors in the right stoichiometry [60] or the inclusion of potential human specific factors may improve the efficiency and reproducibility of iPSC generation. Indeed, a broad number of studies have identified factors able to improve reprogramming efficiency of mouse cells (i.e. increasing the number of reprogrammed cells) however such factors are rarely as efficient with human cells. In addition, the qualitative effect of these factors is difficult to evaluate with human cells due the absence of precise test such as tetraploid complementation. Thus, the discovery of human specific pluripotency factors combined with tailored reprogramming protocols (factors, stoichiometry and timing) could help to derive high quality hiPSC lines. Crucially, not only the number of reprogrammed cells, but also their quality in terms of absence of undesirable genetic or epigenetic variations is paramount and could 
also be influenced by the precise reprogramming avenue. To ensure the best quality of pluripotent stem cells, especially for clinical applications, regular and detailed testing is essential to avoid the occurrence of oncogenic mutations or other unwanted alterations $[61,62]$.

Another alternative to bypass the variability between hPSCs consist in purifying proliferative progenitors during the process of differentiation. Such approach has been successfully applied to isolate progenitors from the 3 germ layers endoderm $[63,64]$ or foregut endoderm [65], neural stem cells [66] and mesoderm [67]. Whether this approach could be useful to decrease variability between different lines however remains to be shown. Indeed, variability in the capacity of differentiation is likely to occur at different stages of differentiation and thus could require purification of several intermediates.

Ultimately, the best approach to bypass variability in differentiation and to develop universal protocols of differentiation is to acquire a better understanding of the molecular mechanisms directing hPSCs cell fate decisions and especially how the genetic and epigenetic background can influence these mechanisms. Thus, detailed studies are needed to discover the interplays by which signalling pathways directing differentiation in hPSCs orchestrate transcriptional networks and epigenetic states and how in turn genomic variability can influence the activity of key regulators. This knowledge will allow us to systematically tailor protocols of differentiation to specific genetic backgrounds. Ultimately, some of these mechanisms could also apply to adult somatic stem cells and thus deliver new insights into the mechanisms controlling the individual capacity for tissue repair and organ homeostasis.

Figure 1: Sources of Variability

Figure 2: Signalling pathways in PSC differentiation

Table: Initiatives generating large numbers of iPSCs

\begin{tabular}{|c|c|c|c|}
\hline $\begin{array}{l}\text { Name of } \\
\text { the } \\
\text { project }\end{array}$ & Web site & $\begin{array}{l}\text { hiPSC } \\
\text { lines } \\
\text { (Current/ } \\
\text { Objective) } \\
\end{array}$ & Distributor \\
\hline $\mathrm{HISPCl}$ & http://www.hipsci.org/ & $500 / 800$ & $\begin{array}{l}\text { ECACC } \\
\text { (www.pheculturecollections.org.uk/pr } \\
\text { oducts/celllines/ipsc/) }\end{array}$ \\
\hline NYSCF & http://nyscf.org/ & $21 / ?$ & NYSCF \\
\hline WiCELL & www.wicell.org & 1200 & WiCell \\
\hline CIRM & $\begin{array}{l}\text { www.cirm.ca.gov/rese } \\
\text { archers/ipsc- } \\
\text { repository }\end{array}$ & 1200 & $\begin{array}{l}\text { Coriell } \\
\text { (https://catalog.coriell.org/1/CIRM) }\end{array}$ \\
\hline EBISCs & https://www.ebisc.org/ & $367 / 10000$ & EBISCs \\
\hline NextGen & $\begin{array}{l}\text { http://www.cell.com/c } \\
\text { ell-stem- } \\
\underline{\text { cell/fulltext/S1934- }} \\
\underline{5909(17) 30092-9}\end{array}$ & $? / 2000$ & WiCell \\
\hline
\end{tabular}




\section{References:}

* of special interest

** of outstanding interest

1. Thomson JA, Itskovitz-Eldor J, Shapiro SS, Waknitz MA, Swiergiel JJ, Marshall VS, Jones JM: Embryonic stem cell lines derived from human blastocysts. Science 1998, 282:1145-7.

2. Takahashi K, Tanabe K, Ohnuki M, Narita M, Ichisaka T, Tomoda K, Yamanaka S: Induction of Pluripotent Stem Cells from Adult Human Fibroblasts by Defined Factors. Cell 2007, 131:861-872.

3. Osafune K, Caron L, Borowiak M, Martinez RJ, Fitz-Gerald CS, Sato Y, Cowan CA, Chien KR, Melton DA: Marked differences in differentiation propensity among human embryonic stem cell lines. Nat. Biotechnol. 2008, 26:313-5.

4. Boulting GL, Kiskinis E, Croft GF, Amoroso MW, Oakley DH, Wainger BJ, Williams DJ, Kahler DJ, Yamaki M, Davidow L, et al.: A functionally characterized test set of human induced pluripotent stem cells. Nat. Biotechnol. 2011, 29:279-86.

5. Bock C, Kiskinis E, Verstappen G, Gu H, Boulting G, Smith ZD, Ziller M, Croft GF, Amoroso MW, Oakley DH, et al.: Reference Maps of human ES and iPS cell variation enable high-throughput characterization of pluripotent cell lines. Cell 2011, 144:439-52.

6. Kattman SJ, Witty AD, Gagliardi M, Dubois NC, Niapour M, Hotta A, Ellis J, Keller G: Stage-specific optimization of activin/nodal and BMP signaling promotes cardiac differentiation of mouse and human pluripotent stem cell lines. Cell Stem Cell 2011, 8:228-40.

7. Blauwkamp TA, Nigam S, Ardehali R, Weissman IL, Nusse R: Endogenous Wnt signalling in human embryonic stem cells generates an equilibrium of distinct lineage-specified progenitors. Nat. Commun. 2012, 3:1070.

8. Jiang W, Wang J, Zhang Y: Histone H3K27me3 demethylases KDM6A and KDM6B modulate definitive endoderm differentiation from human ESCs by regulating WNT signaling pathway. Cell Res. 2013, 23:122-130.

9. Kim H, Lee G, Ganat Y, Papapetrou EP, Lipchina I, Socci ND, Sadelain M, Studer L: miR-371-3 Expression Predicts Neural Differentiation Propensity in Human Pluripotent Stem Cells. Cell Stem Cell 2011, 8:695-706.

10. Nishizawa M, Chonabayashi K, Nomura M, Tanaka A, Nakamura M, Inagaki A, Nishikawa M, Takei I, Oishi A, Tanabe K, et al.: Epigenetic Variation between Human Induced Pluripotent Stem Cell Lines Is an Indicator of Differentiation Capacity. Cell Stem Cell 2016, 19:341-354.

** This study not only shows epigenetic characterisation of the variability of different hiPSC lines, but importantly highlights stage dependent differential sources of functional variability.

11. Ramos-Mejia V, Melen GJ, Sanchez L, Gutierrez-Aranda I, Ligero G, Cortes JL, Real PJ, Bueno C, Menendez P: Nodal/Activin Signaling Predicts Human Pluripotent Stem Cell Lines Prone to Differentiate Toward the Hematopoietic Lineage. Mol. Ther. 2010, 18:2173-2181.

12. Stadtfeld M, Apostolou E, Akutsu H, Fukuda A, Follett $P$, Natesan S, Kono T, Shioda $\mathrm{T}$, Hochedlinger $\mathrm{K}$ : Aberrant silencing of imprinted genes on chromosome 12qF1 
in mouse induced pluripotent stem cells. Nature 2010, 465:175-181.

13. Guenther MG, Frampton GM, Soldner F, Hockemeyer D, Mitalipova M, Jaenisch R, Young RA: Chromatin Structure and Gene Expression Programs of Human Embryonic and Induced Pluripotent Stem Cells. Cell Stem Cell 2010, 7:249-257.

14. Newman AM, Cooper JB: Lab-Specific Gene Expression Signatures in Pluripotent Stem Cells. Cell Stem Cell 2010, 7:258-262.

15. Chung T-L, Brena RM, Kolle G, Grimmond SM, Berman BP, Laird PW, Pera MF, Wolvetang EJ: Vitamin C Promotes Widespread Yet Specific DNA Demethylation of the Epigenome in Human Embryonic Stem Cells. Stem Cells 2010, 28:18481855.

16. Chung T-L, Turner JP, Thaker NY, Kolle G, Cooper-White JJ, Grimmond SM, Pera MF, Wolvetang EJ: Ascorbate Promotes Epigenetic Activation of CD30 in Human Embryonic Stem Cells. Stem Cells 2010, 28:1782-1793.

17. Ruiz S, Diep D, Gore A, Panopoulos AD, Montserrat N, Plongthongkum N, Kumar S, Fung H-L, Giorgetti A, Bilic J, et al.: Identification of a specific reprogrammingassociated epigenetic signature in human induced pluripotent stem cells. Proc. Natl. Acad. Sci. 2012, 109:16196-16201.

18. Lister R, Pelizzola M, Kida YS, Hawkins RD, Nery JR, Hon G, Antosiewicz-Bourget J, O'Malley R, Castanon R, Klugman S, et al.: Hotspots of aberrant epigenomic reprogramming in human induced pluripotent stem cells. Nature 2011, 471:6873.

19. Johannesson B, Sagi I, Gore A, Paull D, Yamada M, Golan-Lev T, Li Z, LeDuc C, Shen Y, Stern S, et al.: Comparable Frequencies of Coding Mutations and Loss of Imprinting in Human Pluripotent Cells Derived by Nuclear Transfer and Defined Factors. Cell Stem Cell 2014, 15:634-642.

20. Koyanagi-Aoi M, Ohnuki M, Takahashi K, Okita K, Noma H, Sawamura Y, Teramoto I, Narita M, Sato Y, Ichisaka T, et al.: Differentiation-defective phenotypes revealed by large-scale analyses of human pluripotent stem cells. Proc. Natl. Acad. Sci. U. S. A. 2013, 110:20569-74.

21. Panopoulos AD, Smith EN, Arias AD, Shepard PJ, Hishida Y, Modesto V, Diffenderfer KE, Conner C, Biggs W, Sandoval E, et al:: Aberrant DNA Methylation in Human iPSCs Associates with MYC-Binding Motifs in a Clone-Specific Manner Independent of Genetics. Cell Stem Cell 2017, 20:505-517.e6.^

* iPSCs derived from monocygotic twins are used to investigate the influence of genetic background and other factors on heterogeneity and DNA methylation. Non-genetic factors including MYC are pointed out to be important.

22. Nakagawa M, Koyanagi M, Tanabe K, Takahashi K, Ichisaka T, Aoi T, Okita K, Mochiduki Y, Takizawa N, Yamanaka S: Generation of induced pluripotent stem cells without Myc from mouse and human fibroblasts. Nat. Biotechnol. 2007, 26:101-106.

23. Wernig M, Meissner A, Cassady JP, Jaenisch R, Ku M, Hochedlinger K, Bernstein $B E$, Jaenisch $R$, Tchieu J, Jaenisch R, et al.: c-Myc is dispensable for direct reprogramming of mouse fibroblasts. Cell Stem Cell 2008, 2:10-2.

24. Butcher LM, Ito M, Brimpari M, Morris TJ, Soares FAC, Ährlund-Richter L, Carey N, Vallier L, Ferguson-Smith AC, Beck S: Non-CG DNA methylation is a biomarker for assessing endodermal differentiation capacity in pluripotent stem cells. Nat. 
Commun. 2016, 7:10458.

* Emphasising the importance of non-CG methylation as a factor influencing functional variability.

25. Ghosh Z, Wilson KD, Wu Y, Hu S, Quertermous T, Wu JC: Persistent Donor Cell Gene Expression among Human Induced Pluripotent Stem Cells Contributes to Differences with Human Embryonic Stem Cells. PLoS One 2010, 5:e8975.

26. Marchetto MCN, Yeo GW, Kainohana O, Marsala M, Gage FH, Muotri AR: Transcriptional Signature and Memory Retention of Human-Induced Pluripotent Stem Cells. PLoS One 2009, 4:e7076.

27. Kim K, Zhao R, Doi A, Ng K, Unternaehrer J, Cahan P, Hongguang H, Loh Y-H, Aryee $M J$, Lensch MW, et al.: Donor cell type can influence the epigenome and differentiation potential of human induced pluripotent stem cells. Nat. Biotechnol. 2011, 29:1117-1119.

28. Ohi Y, Qin H, Hong C, Blouin L, Polo JM, Guo T, Qi Z, Downey SL, Manos PD, Rossi DJ, et al.: Incomplete DNA methylation underlies a transcriptional memory of somatic cells in human iPS cells. Nat. Cell Biol. 2011, 13:541-549.

29. Bar-Nur O, Russ HA, Efrat S, Benvenisty N: Epigenetic Memory and Preferential Lineage-Specific Differentiation in Induced Pluripotent Stem Cells Derived from Human Pancreatic Islet Beta Cells. Cell Stem Cell 2011, 9:17-23.

30. Sanchez-Freire V, Lee AS, Hu S, Abilez OJ, Liang P, Lan F, Huber BC, Ong S-G, Hong WX, Huang M, et al.: Effect of Human Donor Cell Source on Differentiation and Function of Cardiac Induced Pluripotent Stem Cells. J. Am. Coll. Cardiol. 2014, 64:436-448.

31. Schuster J, Halvardson J, Pilar Lorenzo L, Ameur A, Sobol M, Raykova D, Annerén G, Feuk L, Dahl N: Transcriptome Profiling Reveals Degree of Variability in Induced Pluripotent Stem Cell Lines: Impact for Human Disease Modeling. Cell. Reprogram. 2015, 17:327-337.

32. Kajiwara M, Aoi T, Okita K, Takahashi R, Inoue H, Takayama N, Endo H, Eto K, Toguchida J, Uemoto S, et al.: Donor-dependent variations in hepatic differentiation from human-induced pluripotent stem cells. Proc. Natl. Acad. Sci. 2012, 109:12538-12543.

33. Burrows CK, Banovich NE, Pavlovic BJ, Patterson K, Gallego Romero I, Pritchard JK, Gilad Y: Genetic Variation, Not Cell Type of Origin, Underlies the Majority of Identifiable Regulatory Differences in iPSCs. PLOS Genet. 2016, 12:e1005793.

34. Kyttälä A, Moraghebi R, Valensisi C, Kettunen J, Andrus C, Pasumarthy KK, Nakanishi M, Nishimura K, Ohtaka M, Weltner J, et al.: Genetic Variability Overrides the Impact of Parental Cell Type and Determines iPSC Differentiation Potential. Stem Cell Reports 2016, 6:200-212.

* Comparison of iPSCs derived from fibroblasts or peripheral blood from different donors indicating that genetic background seems to be more important than epigenetic memory.

35. Choi J, Lee S, Mallard W, Clement K, Tagliazucchi GM, Lim H, Choi IY, Ferrari F, Tsankov AM, Pop R, et al.: A comparison of genetically matched cell lines reveals the equivalence of human iPSCs and ESCs. Nat. Biotechnol. 2015, 33:1173-81.

* A comprehensive comparison of human ES and iPS lines, importantly with the same 
genetic background.

36. Mallon BS, Hamilton RS, Kozhich OA, Johnson KR, Fann YC, Rao MS, Robey PG: Comparison of the molecular profiles of human embryonic and induced pluripotent stem cells of isogenic origin. Stem Cell Res. 2014, 12:376-386.

37. Perales-Clemente E, Cook AN, Evans JM, Roellinger S, Secreto F, Emmanuele V, Oglesbee D, Mootha VK, Hirano M, Schon EA, et al.: Natural underlying mtDNA heteroplasmy as a potential source of intra-person hiPSC variability. EMBO J. 2016, 35:1979-1990.

* Interesting paper introducing mitochondrial DNA as another potential source or PSC variability.

38. Rouhani F, Kumasaka N, de Brito MC, Bradley A, Vallier L, Gaffney D: Genetic Background Drives Transcriptional Variation in Human Induced Pluripotent Stem Cells. PLoS Genet. 2014, 10:e1004432.

39. Carcamo-Orive I, Hoffman GE, Cundiff P, Beckmann ND, D'Souza SL, Knowles JW, Patel A, Papatsenko D, Abbasi F, Reaven GM, et al.: Analysis of Transcriptional Variability in a Large Human iPSC Library Reveals Genetic and Non-genetic Determinants of Heterogeneity. Cell Stem Cell 2017, 20:518-532.e9.

** Recent and comprehensive study of 317 different iPSC lines identifying candidates for variability in differentiation efficiency. The chromatin regulator polycomb is highlighted as one such factor.

40. DeBoever C, Li H, Jakubosky D, Benaglio P, Reyna J, Olson KM, Huang H, Biggs W, Sandoval E, D'Antonio M, et al.: Large-Scale Profiling Reveals the Influence of Genetic Variation on Gene Expression in Human Induced Pluripotent Stem Cells. Cell Stem Cell 2017, 20:533-546.e7.

* Large study characterising 215 different iPSC lines using RNA-seq. This can serve as a good resource for the identification of quantitative trait loci.

41. Warren CR, O'Sullivan JF, Friesen M, Becker CE, Zhang X, Liu P, Wakabayashi Y, Morningstar JE, Shi X, Choi J, et al.: Induced Pluripotent Stem Cell Differentiation Enables Functional Validation of GWAS Variants in Metabolic Disease. Cell Stem Cell 2017, 20:547-557.e7.

42. Cannavò E, Koelling N, Harnett D, Garfield D, Casale FP, Ciglar L, Gustafson HE, Viales RR, Marco-Ferreres R, Degner JF, et al.: Genetic variants regulating expression levels and isoform diversity during embryogenesis. Nature 2017, 541:402-406.

* Very interesting study of the mechanisms behind expression variation during drosophila development. It remains to be determined if similar allelic interactions within enhancers also have a major influence in human cells.

43. Pashos EE, Park Y, Wang X, Raghavan A, Yang W, Abbey D, Peters DT, Arbelaez J, Hernandez M, Kuperwasser N, et al.: Large, Diverse Population Cohorts of hiPSCs and Derived Hepatocyte-like Cells Reveal Functional Genetic Variation at Blood Lipid-Associated Loci. Cell Stem Cell 2017, 20:558-570.e10.

* This study is using a large number of hiPSCs to discover gene variants that influence cellular phenotypes in differentiated hepatocyte-like cells suggesting that iPS based systems can be used to uncover factors contributing to complex human diseases.

44. Marchetto MCN, Carromeu C, Acab A, Yu D, Yeo GW, Mu Y, Chen G, Gage FH, Muotri AR: A Model for Neural Development and Treatment of Rett Syndrome 
Using Human Induced Pluripotent Stem Cells. Cell 2010, 143:527-539.

45. Mekhoubad S, Bock C, de Boer AS, Kiskinis E, Meissner A, Eggan K: Erosion of Dosage Compensation Impacts Human iPSC Disease Modeling. Cell Stem Cell 2012, 10:595-609.

46. Salomonis N, Dexheimer PJ, Omberg L, Schroll R, Bush S, Huo J, Schriml L, Ho Sui $S$, Keddache M, Mayhew C, et al.: Integrated Genomic Analysis of Diverse Induced Pluripotent Stem Cells from the Progenitor Cell Biology Consortium. Stem Cell Reports 2016, 7:110-125.

47. Anguera MC, Sadreyev R, Zhang Z, Szanto A, Payer B, Sheridan SD, Kwok S, Haggarty SJ, Sur M, Alvarez J, et al.: Molecular Signatures of Human Induced Pluripotent Stem Cells Highlight Sex Differences and Cancer Genes. Cell Stem Cell 2012, 11:75-90.

48. Pick M, Stelzer Y, Bar-Nur O, Mayshar Y, Eden A, Benvenisty N: Clone- and GeneSpecific Aberrations of Parental Imprinting in Human Induced Pluripotent Stem Cells. Stem Cells 2009, 27:2686-2690.

49. Chamberlain SJ, Chen P-F, Ng KY, Bourgois-Rocha F, Lemtiri-Chlieh F, Levine ES, Lalande M: Induced pluripotent stem cell models of the genomic imprinting disorders Angelman and Prader-Willi syndromes. Proc. Natl. Acad. Sci. 2010, 107:17668-17673.

50. Nazor KL, Altun G, Lynch C, Tran H, Harness JV, Slavin I, Garitaonandia I, Müller F$\mathrm{J}$, Wang Y-C, Boscolo FS, et al.: Recurrent Variations in DNA Methylation in Human Pluripotent Stem Cells and Their Differentiated Derivatives. Cell Stem Cell 2012, 10:620-634.

51. Hiura H, Toyoda M, Okae H, Sakurai M, Miyauchi N, Sato A, Kiyokawa N, Okita H, Miyagawa $\mathrm{Y}$, Akutsu $\mathrm{H}$, et al.: Stability of genomic imprinting in human induced pluripotent stem cells. BMC Genet. 2013, 14:32.

52. Stadtfeld M, Apostolou E, Ferrari F, Choi J, Walsh RM, Chen T, Ooi SSK, Kim SY, Bestor TH, Shioda T, et al.: Ascorbic acid prevents loss of Dlk1-Dio3 imprinting and facilitates generation of all-iPS cell mice from terminally differentiated $B$ cells. Nat. Genet. 2012, 44:398-405.

53. Holm TM, Jackson-Grusby L, Brambrink T, Yamada Y, Rideout WM, Jaenisch R: Global loss of imprinting leads to widespread tumorigenesis in adult mice. Cancer Cell 2005, 8:275-285.

54. Tesarova L, Simara P, Stejskal S, Koutna I: The Aberrant DNA Methylation Profile of Human Induced Pluripotent Stem Cells Is Connected to the Reprogramming Process and Is Normalized During In Vitro Culture. PLoS One 2016, 11:e0157974.

55. Nishino K, Umezawa A: DNA methylation dynamics in human induced pluripotent stem cells. Hum. Cell 2016, 29:97-100.

56. Hussein SM, Batada NN, Vuoristo S, Ching RW, Autio R, Närvä E, Ng S, Sourour M, Hämäläinen $\mathrm{R}$, Olsson $\mathrm{C}$, et al.: Copy number variation and selection during reprogramming to pluripotency. Nature 2011, 471:58-62.

57. Lund RJ, Närvä E, Lahesmaa R: Genetic and epigenetic stability of human pluripotent stem cells. Nat. Rev. Genet. 2012, 13:732-744.

58. Paull D, Sevilla A, Zhou H, Hahn AK, Kim H, Napolitano C, Tsankov A, Shang L, Krumholz K, Jagadeesan $P$, et al.: Automated, high-throughput derivation, characterization and differentiation of induced pluripotent stem cells. Nat. 
Methods 2015, 12:885-892.

59. Takashima Y, Guo G, Loos R, Nichols J, Ficz G, Krueger F, Oxley D, Santos F, Clarke J, Mansfield W, et al.: Resetting Transcription Factor Control Circuitry toward Ground-State Pluripotency in Human. Cell 2014, 158:1254-1269.

60. Chin MH, Pellegrini M, Plath K, Lowry WE: Molecular Analyses of Human Induced Pluripotent Stem Cells and Embryonic Stem Cells. Cell Stem Cell 2010, 7:263269.

61. Merkle FT, Ghosh S, Kamitaki N, Mitchell J, Avior Y, Mello C, Kashin S, Mekhoubad $S$, llic $D$, Charlton $M$, et al.: Human pluripotent stem cells recurrently acquire and expand dominant negative P53 mutations. Nature 2017, 545:229-233.

62. Andrews P, Baker D, Benvinisty N, Miranda B, Bruce K, Br?stle O, Choi M, Choi Y-M, Crook J, de Sousa $P$, et al.: Points to consider in the development of seed stocks of pluripotent stem cells for clinical applications: International Stem Cell Banking Initiative (ISCBI). Regen. Med. 2015, 10:1-44.

63. Sneddon JB, Borowiak M, Melton DA: Self-renewal of embryonic-stem-cell-derived progenitors by organ-matched mesenchyme. Nature 2012, 491:765.

64. Cheng X, Ying L, Lu L, Galvão AM, Mills JA, Lin HC, Kotton DN, Shen SS, Nostro $\mathrm{MC}$, Choi JK, et al.: Self-renewing endodermal progenitor lines generated from human pluripotent stem cells. Cell Stem Cell 2012, 10:371-84.

65. Hannan NF, Fordham R, Syed Y, Moignard V, Berry A, Bautista R, Hanley N, Jensen K, Vallier L: Generation of Multipotent Foregut Stem Cells from Human Pluripotent Stem Cells. Stem Cell Reports 2013, 1:293-306.

66. Koch P, Opitz T, Steinbeck JA, Ladewig J, Brustle O: A rosette-type, self-renewing human ES cell-derived neural stem cell with potential for in vitro instruction and synaptic integration. Proc. Natl. Acad. Sci. 2009, 106:3225-3230.

67. Birket MJ, Ribeiro MC, Verkerk AO, Ward D, Leitoguinho AR, den Hartogh SC, Orlova V V, Devalla HD, Schwach V, Bellin M, et al.: Expansion and patterning of cardiovascular progenitors derived from human pluripotent stem cells. Nat. Biotechnol. 2015, 33:970-9. 


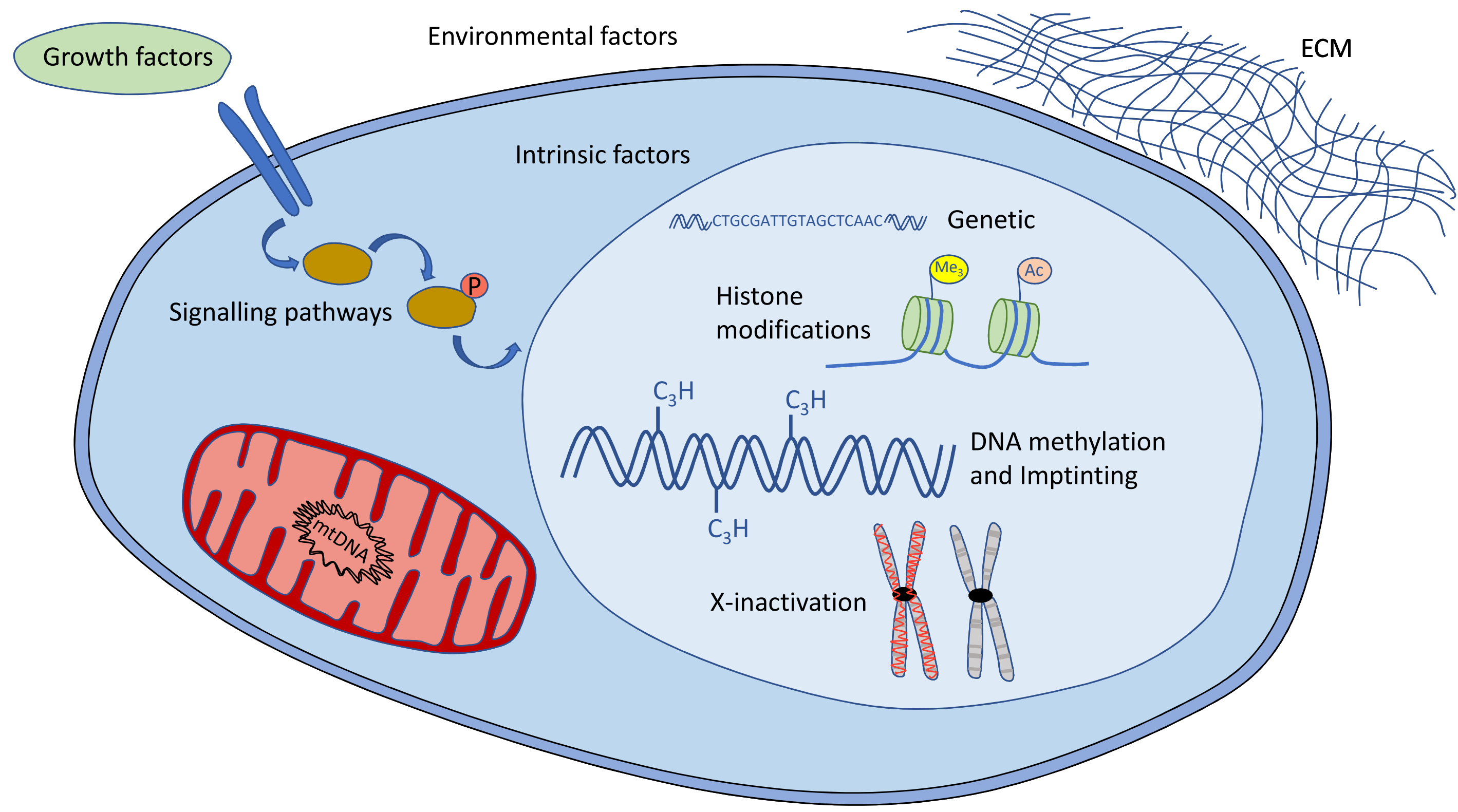


Human pluripotent stem cells

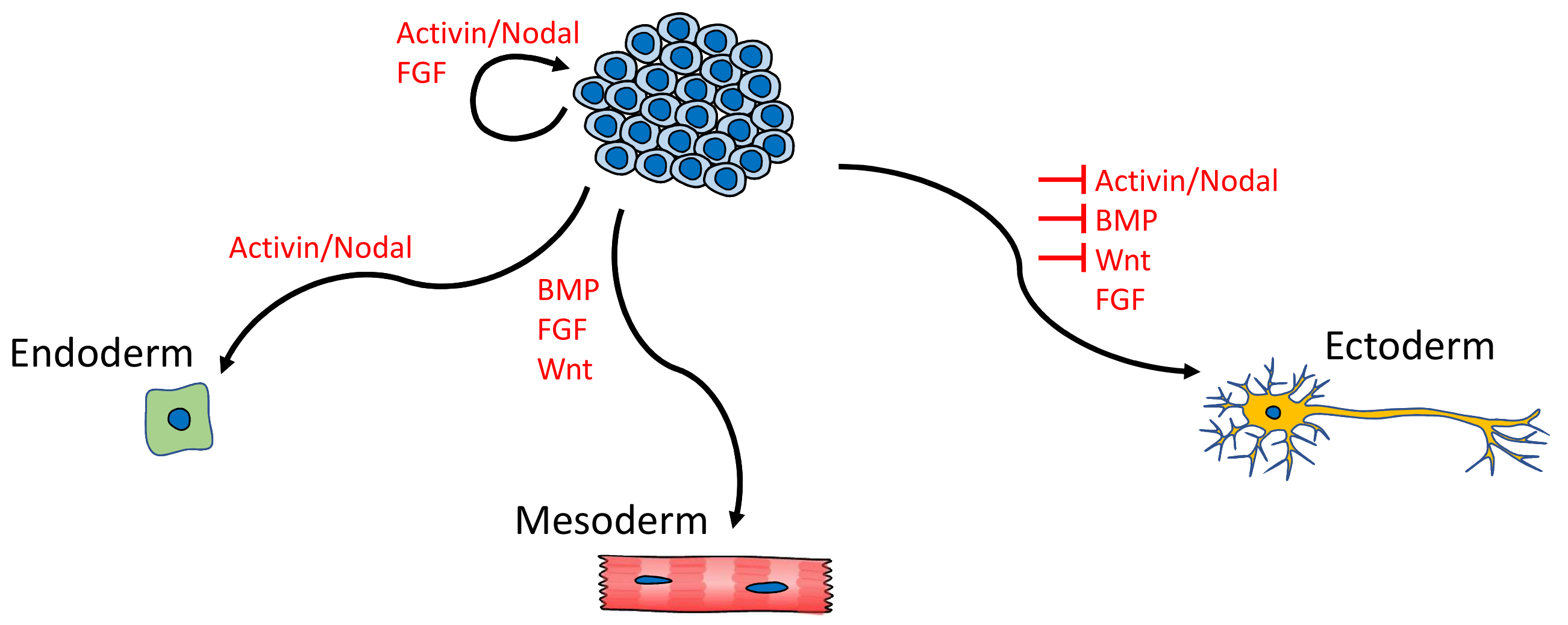

